\title{
New Quinacridone Pigments $\begin{gathered}\text { UDC } \\ 667.622 .32 \\ : 668.883 .81\end{gathered}$
}

\author{
Kunihiko TaKagi, Kazuyuki Kurosu \\ and Isao FuJII \\ Dainippon Ink \& Chemicals Co., Ltd.
}

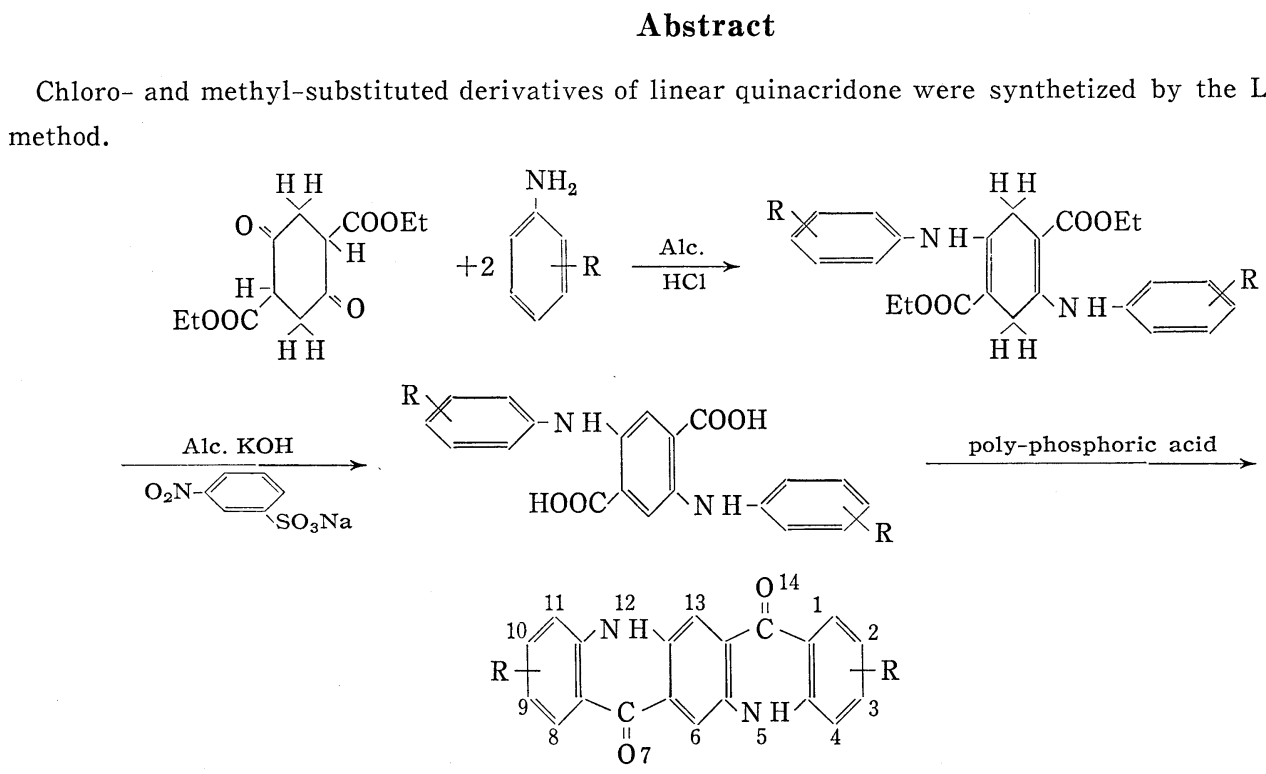

The effects of substituent and the crystal form on colour were studied. The derivatives synthetized were 4,11-dichloro, 3,10-dichloro-, 2,9-dichloro-, 4, 11-dimethyl-, 3, 10-dimethyl-, 2, 9-dimethyl-, 2, 4, 9, 11-tetramethyl-, and 1,2,4,8,9,11-hexachloro-quinacridone. Various crystal forms were prepared by the following methods.

i. precipitation from conc. $\mathrm{H}_{2} \mathrm{SO}_{4}$ solution by dilution with water

ii. precipitation from dimethylformamide/ $10 \%$ alc. $\mathrm{KOH}$ solution by dilution with water

iii. refluxing in organic solvents

vi. milling with organic solvents and $\mathrm{NaCl}$ in a ball mill

The colour of the pigments ranged from yellowish scarlet to reddish violet. The number of crystal forms was from 2 to 4 for each derivative. The colour differences among various crystal forms of the substituted quinacridones were smaller than those of the non-substituted one. In organic solvents: the crystal forms of the methyl derivatives were more easily transformed than those of the chloro. derivatives.

Itabashi-ku, Tokyo 


\title{
新規なキナクリドン顔料 $\begin{aligned} & \text { UDC } \\ & 667.622 .32 \\ & : 668.883 .81\end{aligned}$
}

高木邦彦*・黒須収之*・藤井 勲*

\author{
要旨
}

線状キナクリドン（キン- $(2,3 \mathrm{~b})$ アクリジン $-5,12(7,14)$ ジオン) の塩素拉よびメチル置換 体, 8 種を合成し, 色相に対する置換基の効果拉よび結晶形と色相との関倸について検討し た。これらの置換キナクリドンは，ジェチルサクシニルコハク酸より $2,5-$-ジアリルアミノテ レフタル酸を得,さらにこれをポリリン酸 $\left(115 \% \mathrm{H}_{3} \mathrm{PO}_{4}\right)$ で脱水閉環する方法により合成さ れた。後処理法としては，(1)酸処理法，（2）アルカリ性ジメチルホルムアミド処理法，（3） 有機溶媒中での竟沸処理法, および (4)ボールミリング処理法をとった。生成物につき, 自記 分光光度計による測色拈よびX線回折による結晶形の判定を行なった結果は次のようである。

i ）黄橙色〜赤紫色の顔料が得られた。

ii）各置換キナクリドンは, $2 \sim 4$ 個の結晶形が存在する。

iii）結晶形の相違による色相の差は，2,9-ジクロル和よび 2,9 ジメチル置換体を除き, 無置 換体よりも小さい。

iv）有機溶媒中での結晶転移性は, メチル置換体の方が塩素置換体よりも大きい傾向にある。

\section{1. 緒}

言

赤色系の有機顔料として近年ますますその需要が増加 乙ているキナクリドン系顔料は, 次に示される構造式に 和いて置換基のない，すなわち $\mathrm{R} か ゙ \mathrm{H}$ の線状キナクリド ンが主体であり, 色相叔よび多形現象についての詳しい 報告がある。

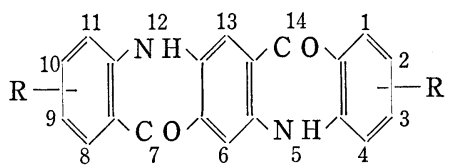

しかし Rが H以外の置換キナクリドンに関しては色相 のみの記載にとどまり, 結晶形と色相との関係について の報告は少ない。著者らは, 数ある置換キナクリドンの うち，Rが塩素あるいはメチル基を有する 8 種の顔料を 合成し, 色相に対する置換基の効果拈よび結晶形々色相 との関係について検討したので報告する。

合成は, Liebermann の方法1) に準じ, 図-1 記載の 方法に従って，ジェチルサクシニルコハク酸とアニリン 類との縮合を行ない， 2,5 -ジアリルアミノ-3, 6-ジヒド ロテレフタル酸ジェチルエステルを生成させ, これを酸

昭 43.3.11 受理

*大日本インキ化学工業 (株) 德丸工場

東京都板橋区新河岸 $1-3-1$

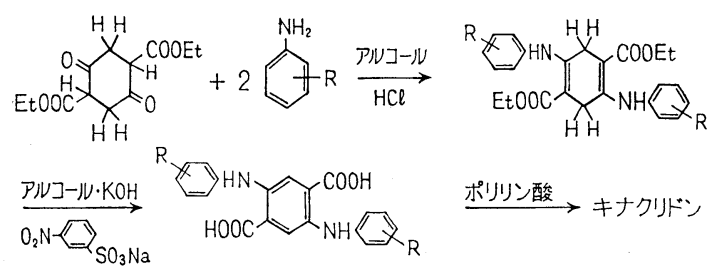

図-1 キナクリドンの経路

化, 加水分解することにより，2,5-ジアリルアミノテレ フタル酸とする。さらにこれをポリリン酸により脱水閉 環してキナクリドンを合成した。

測色は, 生成物をメラミン・アルキド樹脂塗料とし, これをブリキ板に焼付け塗装したものにつき自記分光光 度計により行なった。また, 結晶形の判定は粉末法によ るX線回折で行なった。

\section{2. 実験および結果}

\section{$2 \cdot 1$ キナクリドン類の合成}

$2 \cdot 1 \cdot 1 \quad 4,11$-ジクロルキナクリドンの合成 Oークロルアニリン（東京化成, 一級） $25.0 \mathrm{~g}$ とジェチ ルサクシニルコハク酸（鉄興社, $\mathrm{mp} .128 \sim 129^{\circ} \mathrm{C}$ ) 20.0 $\mathrm{g}$ 叔よび塩酸 (35\%) $1.3 \mathrm{~g}$ をエタノール（東京化成, 一級） $200 \mathrm{~g}$ 中に入れ，6時間還流下反応させた。この 反応液中に $50 \%$ 水酸化カリウム水溶液 $30.0 \mathrm{~g}$ と ロベンゼンーmースルホン酸ナトリウム $40.0 \mathrm{~g}$ を加え, 還 
流下 6 時間反応させたのち, 濃塩酸で中和して冷却し た。次いで, 口過，アルコール洗浄して，2,5-ジ(o-ク ロルアニリノ) テレフタル酸 $25.0 \mathrm{~g}$ を得た。これを500 $\mathrm{g}$ のポリリン酸（日本化学, $115 \% \mathrm{H}_{3} \mathrm{PO}_{4}$ ) そ $150^{\circ} \mathrm{C}, 3$ 時間かきまぜたのち， $3 l$ の冷水で希釈して結晶化した。 これを口過し，1\%カセイソーダ水溶液 $500 \mathrm{~g}$ で洗浄し た。 $22.0 \mathrm{~g}$ (収率 $61.5 \%$ ）の 4,11-ジクロルキナクリド ン( I )を得た。

\section{分析值 $\mathrm{Cl}: 17.58 \%$}

理論值 $18.64 \%\left(\left(\mathrm{C}_{20} \mathrm{H}_{10} \mathrm{~N}_{2} \mathrm{O}_{2} \mathrm{Cl}_{2}\right.\right.$ として $)$

$2 \cdot 1 \cdot 2$ 他のキナクリドン類の合成

以下, $2 \cdot 1 \cdot 1$ 々同样にしてジェチルサクシニルコハク 酸 $20.0 \mathrm{~g}$, エタノール $200 \mathrm{~g}$ を用いて 7 種類のアニリ ン類（試薬一級または同等精製して使用）と反応させた 結果, 表-1 のようであった。

また，生成物の分析值は 表-2 のようであった。

\section{$2 \cdot 2$ 後処理}

合成された各キナクリドン類の結晶を純粋な結晶形と するために次の方法で処理した。各法を無置換キナクリ ドンに適用した場合に $2 \cdot 2 \cdot 1$ の方法では， $\alpha$ 形（不安定 形), $2 \cdot 2 \cdot 2$ の方法では, $\alpha$-形 $+\gamma$-形, $2 \cdot 2 \cdot 3$ の方法で は, $\beta$-形 (準安定形) 扤よび $2 \cdot 2 \cdot 4$ の方法では, $\gamma$ 形 （安定形，溶媒としてジメチルホルムアミド使用）が得 られる現象を, 結晶形の判定基準とし, 詳細はX $\mathrm{X}$ 線回折 の結果により決定した。

\section{$2 \cdot 2 \cdot 1$ 酸処理（水水中投入）}

I 飞対して，その 10 倍量の濃硫酸（試薬一級，98\%） に $5 \sim 77^{\circ} \mathrm{C}$ 飞执いて溶解したのち，50 倍量の水水中へ投 入すると橙色の析出物（I a) が得られる。このものは $\alpha$ 形 (不安定形) である。

以下同様にして II 〜证について行なった結果は 表-3 に示される。

表-3 表に示されるように，本法で行ならと結晶形が
表-2

\begin{tabular}{|c|c|c|c|c|c|}
\hline 生成物 & & $\mathrm{C}(\%)$ & $\mathrm{H}(\%)$ & $\mathrm{N}(\%)$ & $\mathrm{Cl}(\%)$ \\
\hline \multirow{2}{*}{ III } & 分 析 值 & - & - & 一 & 16.48 \\
\hline & 計 算 值 & - & 一 & - & 18.64 \\
\hline \multirow{2}{*}{ III } & 分 析 值 & - & - & - & 17.46 \\
\hline & 計 算 值 & - & 一 & - & 18.64 \\
\hline \multirow{2}{*}{$\mathbb{N}$} & 分 析 值 & 76.14 & 4.67 & 8.24 & - \\
\hline & 計 算 值 & 77.65 & 4.71 & 8. 24 & - \\
\hline \multirow{2}{*}{ V } & 分 析 值 & 77.17 & 4.68 & 8.40 & 一 \\
\hline & 計 算 值 & 77.65 & 4. 71 & 8.24 & - \\
\hline \multirow{2}{*}{ VI } & 分 析 值 & 76.25 & 4.80 & 8.12 & - \\
\hline & 計 算 值 & 77.65 & 4.71 & 8.24 & - \\
\hline \multirow{2}{*}{ VII } & 分 析 值 & 70.27 & 4.34 & 7.51 & - \\
\hline & 計 算 值 & 78.80 & 5.43 & 7.61 & 一 \\
\hline \multirow{2}{*}{ VIII } & 分 析 值 & - & - & - & 38.24 \\
\hline & 計 算 値 & - & - & - & 41.04 \\
\hline
\end{tabular}

表-3

\begin{tabular}{|c|c|c|c|c|c|}
\hline \multicolumn{2}{|c|}{ 使用クルード顔料 } & \multicolumn{3}{|c|}{ 生 } & 物 \\
\hline 名 称 & 量 $(\mathrm{g})$ & 色 & & 目 & 結 晶 形 \\
\hline II & 10.0 & 赤 & & 色 & 判明せず \\
\hline III & 10.0 & 赤 & 紫 & 色 & 判明せず \\
\hline $\mathrm{N}$ & 10.0 & 黄 & 橙 & 色 & IN a $\alpha$-形 \\
\hline $\mathrm{V}$ & 10.0 & 赤 & & 色 & 判明せず \\
\hline $\mathrm{V}$ & 10.0 & 赤 & 紫 & 色 & 判明せず \\
\hline VII & 10.0 & 赤 & & 色 & VII $a$ - $\alpha$-形 \\
\hline VIII & 10.0 & 黄 & 赤 & 色 & VIIIa: $\alpha$-形 \\
\hline
\end{tabular}

判別し得るものと, 結晶性が悪いために判別し得ないも のがある。 III とついて “unclassified form” として他結 晶形と区別し2)また，Vについては独立した結晶形と

表-1

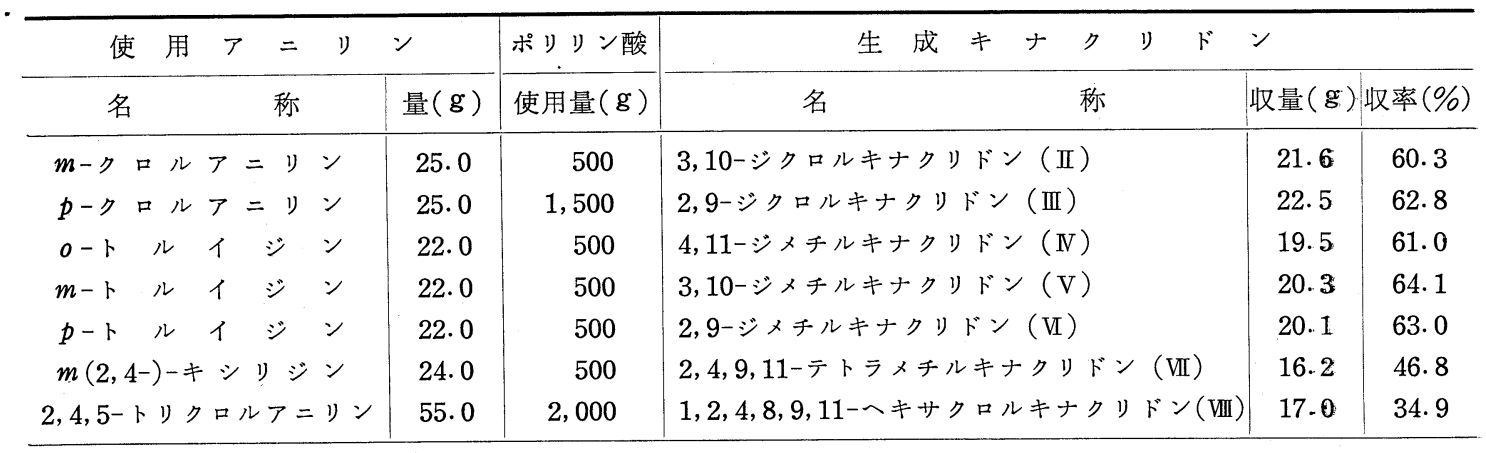


表-4

\begin{tabular}{|c|c|c|c|c|c|}
\hline \multicolumn{2}{|c|}{ 使用クルード顔料 } & \multicolumn{2}{|l|}{ 生 } & & 物 \\
\hline 称 & 量 $(\mathrm{g})$ & 色 & 相 & 結 & 晶 形 \\
\hline II a & 20.0 & & 色 & II a & $\alpha$-形 \\
\hline III $a$ & 20.0 & 赤 & 色 & III a & $\alpha$-形 \\
\hline $\mathrm{Na}$ & 20.0 & 黄 橙 & 色 & $\mathrm{Na}$ & $\alpha$-形 \\
\hline $\mathrm{Va}$ & 20.0 & 赤 & 色 & $\mathrm{Va}$ & $\alpha-$-形 \\
\hline $\mathrm{Va}$ & 20.0 & 赤 紫 & 色 & $\mathrm{VIb}$ & $\beta$-形 \\
\hline VIIa & 20.0 & 赤 & 色 & VII b & $\beta$-形 \\
\hline VIIIa & 20.0 & 帯 黄赤 & 厂色 & VII b & $\beta$-形 \\
\hline
\end{tabular}

判定した報告 ${ }^{3 \sim 5)}$ がみられる。

$2 \cdot 2 \cdot 2$ 酸処理（水添加）

I 飞対して，その 10 倍量の濃硫酸（同上）飞 $5 \sim 7^{\circ} \mathrm{C}$ に执いて溶解したのち, 同温にて, $1 \mathrm{ml} / \mathrm{min}$ の速度で, :20 倍量の水をかきまぜながら添加すると橙色の析出物 （Ｉａ）が得られる。このものは $\alpha$-形（同上）である。

以下同様にして II〜ついて行なった結果は 表-4 壮示される。

IIIについては文献2)の $\beta$-形（準安定形に）相当する。 $2 \cdot 2 \cdot 3$ アルカリ性ジメチルホルムアミド処理

I に対して, その 30 倍量のジメチルホルムアミド (国産化学, 試薬一級, bp. $153^{\circ} \mathrm{C}$ 。以下 D.M.F. と略 称する。）と $10 \%$ アルコール性水酸化カリウムとの溶 液(重量比，5:1) 飞溶解したのち， $1 \mathrm{ml} / \mathrm{min}$ の速度で 15 倍量の水をかきまぜながら添加すると黄橙色の析出 物（I a I $^{\prime}$ が得られる。このものは $\alpha$-形と $\beta$-形の混っ た結晶状態安る。

以下同様にして II〜Uについて行なった結果は 表-5 氾示される。

IIIについては文献2)の $\gamma$ 形（安定形）に相当し，また Uの $\alpha$ 形は文献 ${ }^{3 \sim 5)}$ のスーパーイエロー形に相当する。

$2 \cdot 2 \cdot 4$ 有機溶媒中での惹沸処理
表-5

\begin{tabular}{|c|c|c|c|c|c|c|}
\hline \multicolumn{2}{|c|}{ 使用クルード顔料 } & \multicolumn{3}{|c|}{ 生 } & & 物 \\
\hline 名 称 & 量 $(\mathrm{g})$ & 色 & & 相 & 結 & 晶 形 \\
\hline II a & 20.0 & 赤 & & 色 & II a & $\alpha$-形 \\
\hline III a & 20.0 & 赤 & 紫 & 色 & III $\mathrm{b}$ & $\beta$-形 \\
\hline $\mathrm{Na}$ & 20.0 & 橙 & & 色 & $\mathrm{N} \mathrm{c}$ & $\boldsymbol{\gamma}$-形 \\
\hline $\mathrm{Va}$ & 20.0 & 赤 & & 色 & $\mathrm{Vb}$ & $\beta$-形 \\
\hline $\mathrm{VIa}$ & 20.0 & 赤 & & 色 & $\mathrm{VIa}$ & $\alpha$-形 \\
\hline
\end{tabular}

Iに対して，その 10 倍量の有機溶媒一アセトン, 酢 酸エチル，エチルアルコール，ニトロベンゼン， D. M. F. (以上, 国産化学, 試薬一級品) および N-メチル-2ピロリドン (BASF : bp. 201 202 ${ }^{\circ} \mathrm{C}$ )一に浸セキし, 沸点にて 10 時間煮沸処理する。アセトン, 酢酸エチル, エチルアルコールでは変化なく，ニトロベンゼン， D. M.F. および N-メチル-2-ピロリドンでは黄橙色の粉末 （Ｉｂ）が得られる。このものは $\beta$-形（安定形）である。 な扮使用クルード顔料は 200 mesh 以下とした。

以下同様にして II〜UII について行なった結果は 表-6 に示される。

\section{$2 \cdot 2 \cdot 5$ ミリング処理}

$\mathrm{I}$ を $10 \mathrm{~g}, 150 \mathrm{ml}$ の有機溶媒一キシレンまたは D. M. F. (打の沶の国産化学, 試薬一級)一拈よび $100 \mathrm{~g}$ の精製 食塩と共に, ステンレス製ボールミル（容積 $1 l$, 直径 $9.4 \mathrm{~mm}$ のクロムスチール製ボール $4.5 \mathrm{~kg}$ 入り）中に て, $250 \mathrm{rpm} / \mathrm{min}$ の回転速度で 72 時間ミリングする。 使用有機溶媒, キシンン, D.M.F. いずれの場合とも変 化が認められなかった。

以下同様にして II〜 V について行なった結果は 表-7 に示される。

$2 \cdot 3$ 測定

$2 \cdot 3 \cdot 1$ 色相

表-6

\begin{tabular}{|c|c|c|c|c|c|c|c|}
\hline \multicolumn{2}{|c|}{ 使用クルード顔料 } & \multicolumn{6}{|c|}{ 使 用 有 機 溶 媒 と生成 物 } \\
\hline 称 & 量（g） & アセトン & 酢酸エチル & $\begin{array}{l}\text { × ル } \\
\text { アルコール }\end{array}$ & ニトロベンゼン| & D. M. F. & $\begin{array}{c}\mathrm{N}-x \text { チル }-2- \\
\text { ピロリドン }\end{array}$ \\
\hline II a & 10.0 & $x$ & $x$ & $x$ & $x$ & II b $\quad \beta$-形 & II b $\quad \beta$-形 \\
\hline III a & 10.0 & $x$ & $x$ & $x$ & $\alpha$-形 $+\beta$-形 & III b $\quad \beta$-形 & III b $\quad \beta$-形 \\
\hline IN a & 10.0 & $x$ & $\mathrm{Nb} \quad \beta$-形 & N b $\quad \beta$-形 & $\mathrm{Nb} \quad \beta$-形 & Nc $\quad r$-形 & N c $\boldsymbol{r}$-形 \\
\hline $\mathrm{Va}$ & 10.0 & $x$ & $x$ & $x$ & $\mathrm{Vb} \quad \beta$-形 & Vc $\gamma$-形 & Vc $\gamma$-形 \\
\hline $\mathrm{Va}$ & 10.0 & VIb $\beta$-形 & V b $\beta$-形 & Y b $\beta$-形 & $\mathrm{V}$ b $\beta$-形 & $\mathrm{M} b \quad \beta$-形 & V b $\beta$-形 \\
\hline VIIa & 10.0 & $x$ & $x$ & $x$ & $x$ & UIc $\gamma$-形 & UIb $\delta$-形 \\
\hline VIIIa & 10.0 & $x$ & $\times$ & $x$ & VII b $\beta$-形 & VII b $\beta$-形 & VIIC $\boldsymbol{r}$-形 \\
\hline
\end{tabular}

〔註〕表中×印は転移がみられなかったもの 
表-7

\begin{tabular}{|c|c|c|c|}
\hline \multicolumn{2}{|c|}{ 使用クルード顔料 } & \multicolumn{2}{|c|}{ 使用溶媒拉よび生成物 } \\
\hline 名 & 量 $(\mathrm{g})$ & キシレン & D. M. F. \\
\hline II a & 10.0 & 変化なし & 変化なし \\
\hline III $a$ & 10.0 & III b $\beta$-形 & III b $\quad \beta$-形 \\
\hline IN a & 10.0 & IN b $\beta$-形 & N c $\quad \gamma$-形 \\
\hline $\mathrm{Va}$ & 10.0 & 変化なし & $\mathrm{Vb} \quad \beta$-形 \\
\hline $\mathrm{VIb}$ & 10.0 & $\mathrm{VIa} \alpha$-形 & VI a $\alpha$-形 \\
\hline
\end{tabular}

\section{1) 試料の作成}

不乾性油型アルキド樹脂 (Bechosol J-522-50, n. v. $50 \%$ ) とブチル化メラミン樹脂 (Super Bechamine J820 , n.v. 50\%) との配合樹脂（配合比 $7: 3$ ）中に顔 料（顔料分 10\%）を混合し，ロールで練ったものをブ リキ板にスプレー塗装し, 16 時間放置したのち, $120^{\circ} \mathrm{C}$ で 30 分間要して焼付けした。

表-8

\begin{tabular}{|c|c|c|c|c|c|c|}
\hline \multirow{2}{*}{\multicolumn{2}{|c|}{$\frac{\text { 試 }}{\text { キナクリドン名試料 No. }}$}} & \multicolumn{5}{|c|}{ C.I.E. 色度図による測定值 } \\
\hline & & $x$ & $y$ & $\lambda_{d}$ & $Y$ & $P_{e}$ \\
\hline \multirow{2}{*}{ 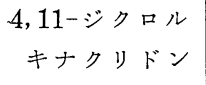 } & I a & 0.5479 & 0.3595 & 599.8 & 11.45 & 75.2 \\
\hline & I b & 0.5811 & 0.3446 & 505.2 & 10.20 & 80.0 \\
\hline \multirow{2}{*}{ 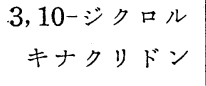 } & II $\mathrm{a}$ & 0.5042 & 0.3193 & 614.2 & 5.70 & 5.28 \\
\hline & II $\mathrm{b}$ & 0.5152 & 0.3182 & 615.0 & 5.25 & 55.5 \\
\hline \multirow{2}{*}{ 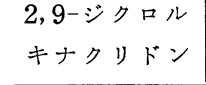 } & III a & 0.4610 & 0.3014 & 649.0 & 4.25 & 36.3 \\
\hline & III $b$ & 0.4521 & 0.2695 & -495.0 & 3.10 & 45.8 \\
\hline \multirow{3}{*}{$\begin{array}{l}4,11 \text {-ジメチル } \\
\text { キナクリドン }\end{array}$} & $\mathrm{Na}$ & 0.5392 & 0.3407 & 604.5 & 6.95 & 66.2 \\
\hline & $\mathrm{Nb}$ & 0.5676 & 0.3259 & 611.5 & 7.35 & 71.2 \\
\hline & $\mathrm{N} \mathrm{C}$ & 0.5911 & 0.3328 & 609.2 & 10.50 & 79.8 \\
\hline \multirow{3}{*}{ 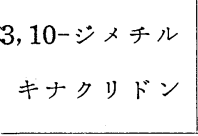 } & $\mathrm{Va}$ & 0.5271 & 0.3163 & 616.5 & 4.95 & 58.0 \\
\hline & $\mathrm{Vb}$ & 0.5223 & 0.3264 & 610.2 & 5.50 & 59.5 \\
\hline & $\mathrm{Vc}$ & 0.5474 & 0.3231 & 612.4 & 6.65 & 65.2 \\
\hline \multirow{2}{*}{ 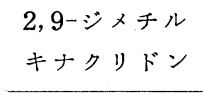 } & VIa & 0.5440 & 0.2901 & 675.0 & 5.60 & 55.8 \\
\hline & VIb & 0.4601 & 0.2831 & -493.7 & 3.20 & 40.7 \\
\hline \multirow{3}{*}{$\begin{array}{l}2,4,9,11- \\
\text { テトラメチル } \\
\text { キナクリドン }\end{array}$} & VIIa & 0.5413 & 0.3223 & 620.5 & 3.90 & 63.5 \\
\hline & VII b & 0.5402 & 0.3103 & 613.0 & 6.75 & 60.0 \\
\hline & VIIC & 0.4787 & 0.3119 & 621.0 & 9.80 & 44.0 \\
\hline \multirow{3}{*}{$\begin{array}{l}1,2,4,8,9,11- \\
\text { ヘキサクロル } \\
\text { キナクリドン }\end{array}$} & VIIIa & 0.5658 & 0.3171 & 616.0 & 8.90 & 68.6 \\
\hline & VIII b & 0.5809 & 0.3309 & 610.0 & 6.75 & 76.0 \\
\hline & VIIIC & 0.6081 & 0.3273 & 611.5 & 10.9 & 82.8 \\
\hline \multirow{3}{*}{$\begin{array}{l}\text { 無置換 } \\
\text { キナクリドン }\end{array}$} & $\alpha$-形 & 0.5000 & 0.3079 & 625.0 & 5.45 & 48.5 \\
\hline & $\beta$-形 & 0.4279 & 0.3045 & 650.0 & 3.70 & 28.3 \\
\hline & $\delta$-形 & 0.5715 & 0.3142 & 618.0 & 9.60 & 69.2 \\
\hline
\end{tabular}

口) 測定器

日立, 自記分光光度計 EPR 2 型

八) 結果

測色結果は 表-8 に示される。なお比較のため無置換 キナクリドンの測定值を併記した。

ジ置換体に打ける色相について, 置換位置で比較する と, 深色性は塩素括よびメチル置換体とも，2，9-位>3， 10-位，>4,11-位の順になっている。無置換キナクリド ン $(\boldsymbol{\gamma}$-形) と比べると，3,10-位就よび 4,11-位は浅色性 であり，2,9-位は無置換キナクリドン $(\beta$-形) よりも深 色性である。また同位の場合, おの沶の最安定形結晶に ついて比較すると, 塩素置換体とメチル置換体とでは, 2,9-位では同程度，3,11-位では塩素置換体，4,11-位で はメチル置換体がやや深色性である。

結晶形の相違による色相の変化は, 無置換キナクリド ンと比べて，2，9-位に塩素およびメチル基が導入された ジ置置体以外はいずれも小さい。 $2 \cdot 3 \cdot 2$ 結晶形

イ）測定器捻よび測定条件

理学電機（株）製 “ガイガーフレックス 2001” Target ; Cu, Filter ; Ni, Voltage; $30 \mathrm{KVP}$, Current; $15 \mathrm{~mA}$, Count Full Scale ; 500 1,000C/S, Time Constant ; $4 \mathrm{sec}$, Chart Speed ; $1 \mathrm{~cm} / \mathrm{m}$, Scanning Speed $; 1^{\circ} / \mathrm{m}$, Receiving Slit ; $0.3 \mathrm{~mm}$, Divergency ; $1^{\circ}$

口) $X$ 線回折像

図-2〜図-22 に示される。

\section{3. 考察}

8 種の置換キナクリドンについて, 色相 と結晶形との関係が判明した。これらのデ 一タは固溶体顔料 6 10) の作成に利用できる。 キナクリドン系顔料の後処理法として, フタロシアニン系顔料で一般に行なわれて いる酸処理法 $(2 \cdot 2 \cdot 1)$ をとると, 非常に Amorphous な状態となり顔料としては適 当でなくなる。この結晶は他結晶形への転 移に拈ける活性化エネルギーが小さいた め, 有機溶媒による煮沸処理 $(2 \cdot 2 \cdot 4)$ によ り，容易に安定形に転移する ${ }^{11)}$ 。

酸処理法 $(2 \cdot 2 \cdot 2)$ とアルカリ性ジメチル ホルムアミド処理法 $(2 \cdot 2 \cdot 3)$ とは, ともに 再結晶法であるが, 両方法です結果を比較 すると，3，10-ジクロルキナクリドンでは 同一結晶形，4,11-ジクロル，2,9-ジクロ ル，4,11-ジメチル，拈よび 3,10-ジメチ 


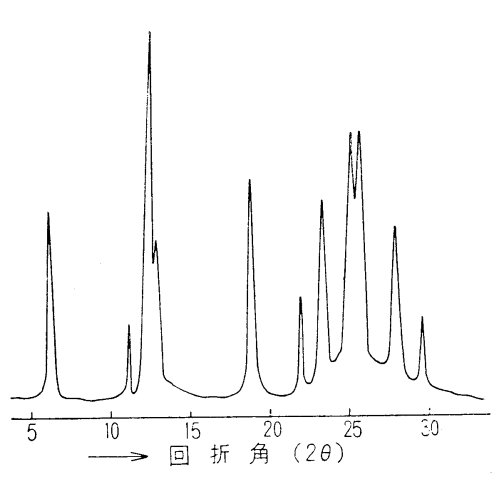

図-2 I a

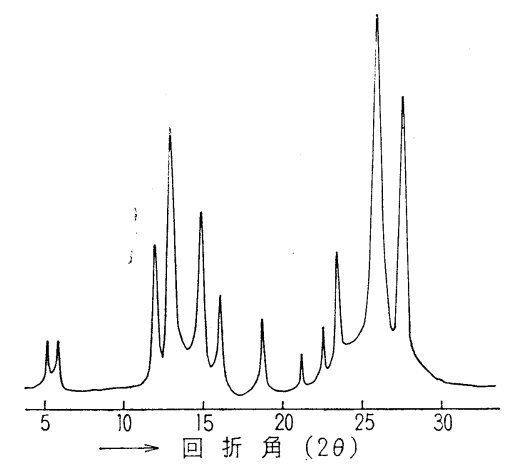

図-5 II b

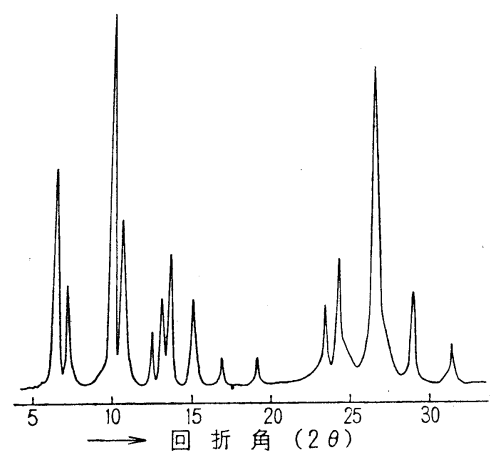

図-8 $\mathrm{N} \mathrm{a}$

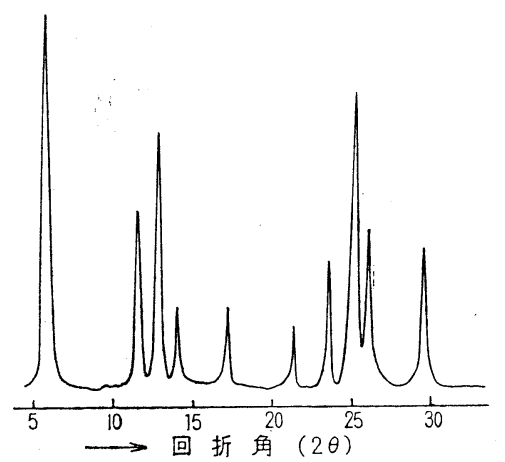

図-11 Va

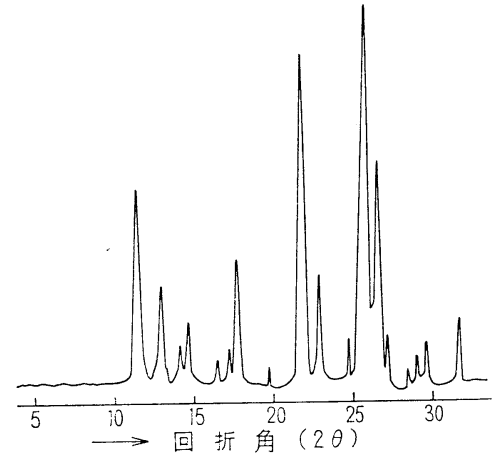

図-3 I b

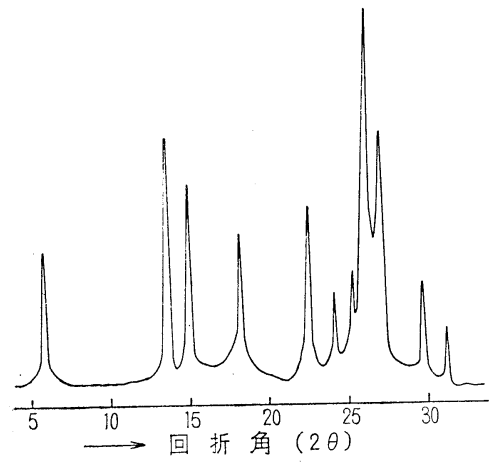

図-6 III a

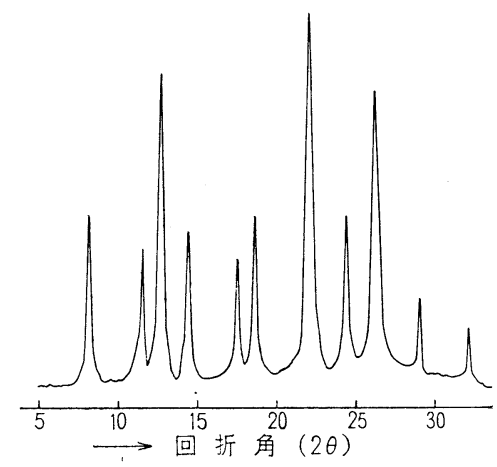

図-9 IN b

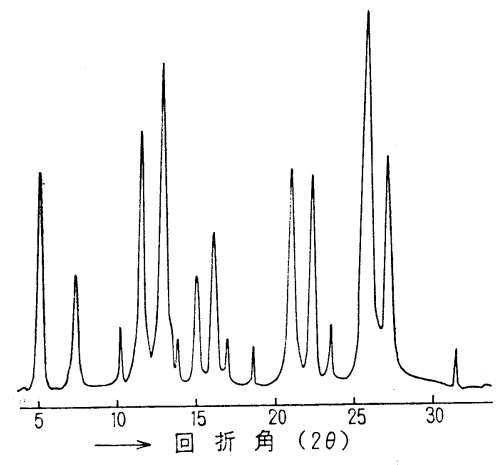

図-12 $\mathrm{Vb}$

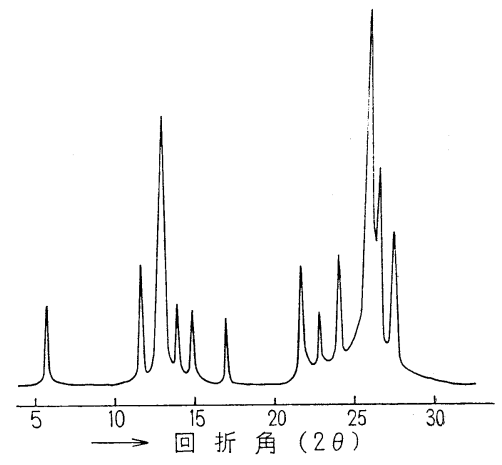

図-4 II a

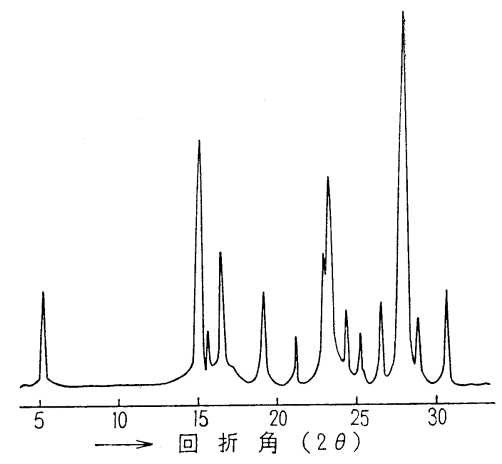

図-7 III b

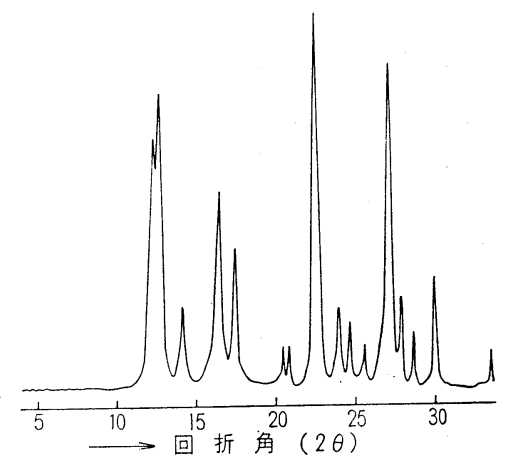

図-10 N c

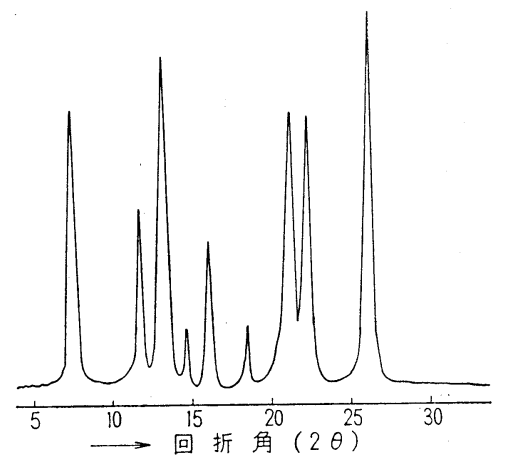

図-13 Vc 


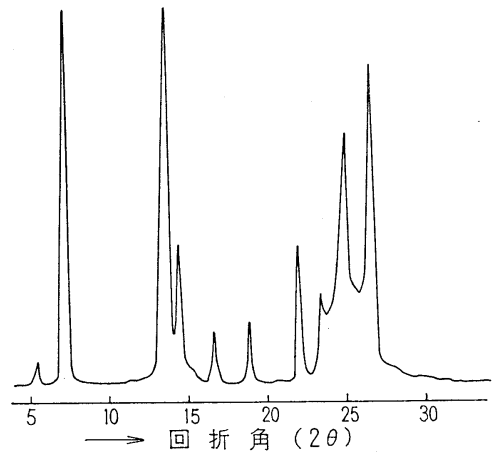

図-14 V a

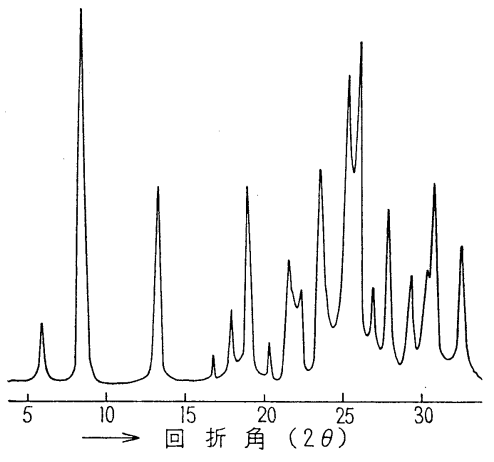

図-17 UIb

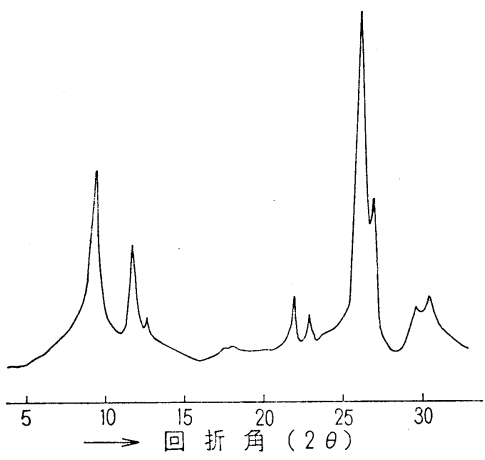

図-20 VIIIa

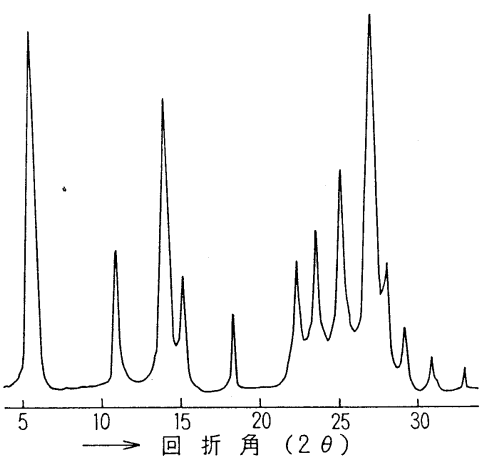

図-15 V b

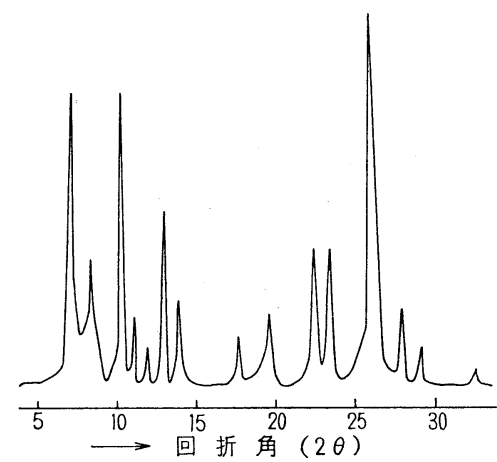

図-18 UII

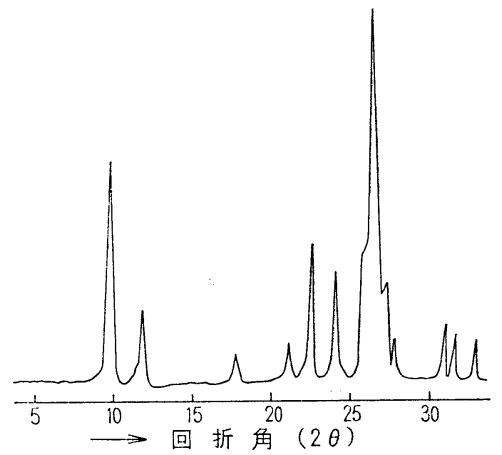

図-21 uIIb

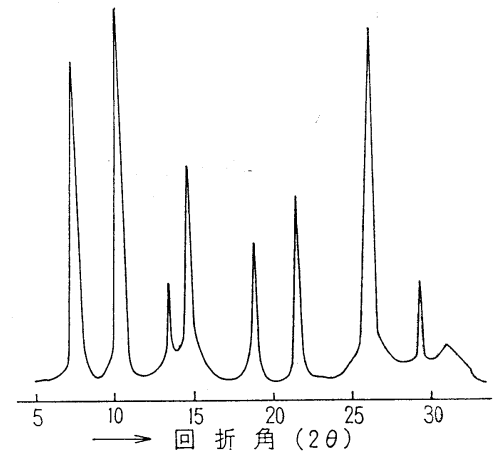

図-16 VIa

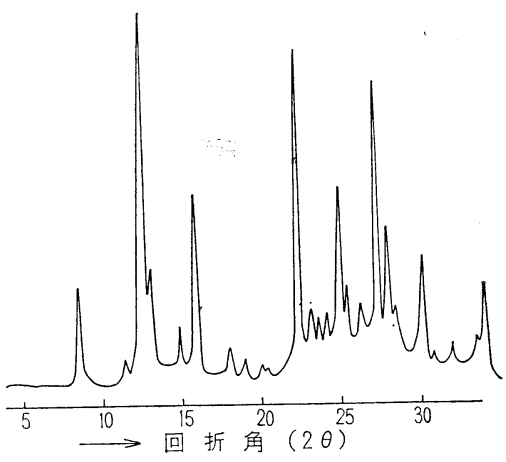

図-19 UId

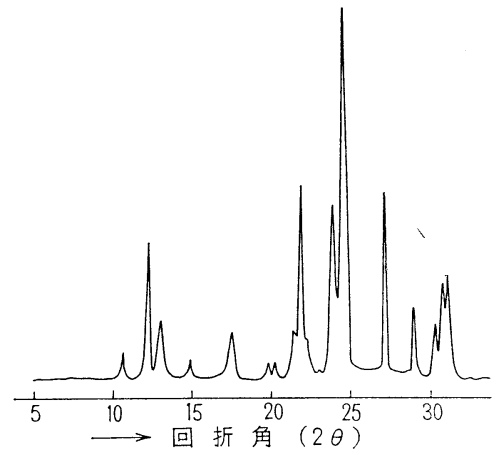

図-22 VIII
ルキナクリドンでは, 後者により, より安定な結晶形, また，2,9-ジメチルキナクリドンでは，前者により，よ り安定な結晶形を得た。この両方法に扣ける溶解状態に おいて, キナクリドンの酸塩括よびアルカリ塩が形成さ れていると考えられる ${ }^{12,13)}$ が，再結晶法と塩の種類によ る生成結晶形との関連性は明確でない。

(本研究は “キナクリドン系顔料に関する研究第 1 報” とする。)

$$
\text { 文 献 }
$$

1) H. Liebermann, Ann. 404, 295 (1914)
2) B. P. 923069

3) U.S.P. 3264298

4) U.S.P. 3264299

5) U.S.P. 3264300

6) B.P. 896916

7) B.P. 955854

8) B.P. 968473

9) B.P. 1017443

10) U.S.P. 3160510

11) B.P. 1004923

12) U.S.P. 3265699

13) B.P. 943957 